\title{
Å forske på eiga speling
}

\section{Analysar av det improviserte samspelet med hjelp av auditiv sonologi}

\author{
Njål Ølnes* \\ NTNU Norges teknisk-naturvitenskapelige universitet
}

\begin{abstract}
Samandrag
Denne artikkelen presenterer, undersøker og diskuterer bruken av auditiv sonologi som metode for å forske på improvisert musikk. Studien er eit eksempel på kunstnarleg forsking, og rettar sine spørsmål frå innsida av ein kunstnarleg praksis. Det underliggande forskingsspørsmålet som har oppstått frå den kunstnarlege praksisen og som vert undersøkt giennom denne artikkelen er: Korleis kan bruk av auditiv sonologi som analysereiskap hjelpe ein musikar-forskar til å forske på musikk innanfrå sin eigen kunstnarlege praksis? Dette spørsmålet vil verte handsama analytisk, refleksivt og kritisk. Konkrete eksempel gjer det muleg å sjå kva auditiv sonologi er og kan gi som metode. Artikkelen vil fokusere på dei metodologiske sidene ved auditiv sonologi, samt vise min konkrete bruk av metoden i eit større forskingsprosjekt. Slik argumenterer artikkelen for at auditiv sonologi er ein nyttig analytisk reiskap for å drive forsking på musikk frå ein hybrid musikar/forskar-ståstad med eit kunstnarleg perspektiv.
\end{abstract}

Nøkkelord: Auditiv sonologi; kunstnarleg forsking; praksisforsking; improvisasjon; analyse, metode

\begin{abstract}
The article presents, investigates and discusses the use of aural sonology as a method for research on improvised music. The study positions itself within the genre of artistic research and poses its research questions from the inside of artistic practice. The research question which has arisen from the artistic practice presented in this article is: How can aural sonology as an analytical tool help a musician/researcher to do research on music from inside the artistic practice? This guiding question has undergone analytical, critical and reflective elaboration, on its passage from the inside out. Full appreciation of aural sonology and its potential as an artistic research method depends on concrete examples. In this article, I therefore refer to and give example of my own specific use of the method in a more comprehensive research project. Based on this, the article argues that aural sonology is an important analytical tool for conducting music research from a hybrid position of musician/researcher in the perspective of artistic practice.
\end{abstract}

Received: May, 2017; Accepted: October, 2017; Published: December, 2017

Keywords: Aural sonology; artistic research; practice-led research; improvisation; analysis; analytical tool

^Correspondence to: Njål Ølnes, Institutt for musikk, NTNU, 7491 Trondheim. Epost: njal.olnes@ntnu.no

(C) 2017 N. Ølnes. This is an Open Access article distributed under the terms of the Creative Commons Attribution 4.0 International License (http://creativecommons.org/licenses/by/4.0/), allowing third parties to copy and redistribute the material in any medium or format and to remix, transform, and build upon the material for any purpose, even commercially, provided the original work is properly cited and states its license.

Citation: N. Ølnes. "Å forske på eiga speling - analysar av det improviserte samspelet med hjelp av auditiv sonologi». fournal for Research in Arts and Sports Education, Special Issue: “A forske med kunsten”,Vol. 1, 2017, pp. 59-78. http://dx. doi. 
Auditiv sonologi ${ }^{1}$ er både ein analysereiskap og ei ferdigheitstrening i å lytte til musikken medan den veks fram. Det er dette praktiske og konkrete som gjer analysemetoden så spesiell i høve forsking på musikk; den tek i bruk ein ferdigheit som mange musikarar, komponistar og publikum deler, nemleg evna til å lytte oppmerksamt til musikk. Eksempla i artikkelen er henta frå mitt doktorgradsarbeid Frå små teikn til store former: Analysar av det improviserte samspelet med hjelp av auditiv sonologi (Ølnes, 2016). Avhandlinga er ei studie av jazzgruppa BMX der eg sjølv spelar saksofon, og undersøker korleis den musikalske formdanninga skjer i eit friimprovisert samspel.

\section{Innleiing: Å forske på eiga utøving}

Min faglege bakgrunn er som jazzsaksofonist og som jazzlærar. Denne tosidigheita, musikar og lærar, har for meg vore komplementær og gått hand i hand i alle år. I ensembleundervisning har eg til dømes måtta konkretisere det eg har oppdaga og erfart i eiga utøving. Og dette har igjen verka konkretiserande på mitt eige (sam) spel. Når eg ville ta undersøkinga og refleksjonen rundt det improviserte samspelet eit steg vidare, gjennom forsking, var det difor viktig å skape ein liknande dialog, her mellom meg som utøvar og forskar. ${ }^{2}$ Viktige spørsmål som utøvar-meg tok med inn i forskinga, var: Korleis kan eg forske på musikken utan «å miste musikken av øyre»? Korleis bringe min eigen praksis og utøving inn i forskinga? Korleis analysere utan å abstrahere seg vekk frå den røyndomen eg vil undersøke? Korleis unngå å skape ein ny røyndom som ikkje er forankra i «musikken sitt språk»? Korleis få med mine medspelarar sin kunnskap inn i forskinga, og gjere forskinga relevant for det utøvande feltet?

Når det kjem til estetiske uttrykk, kan det vera vanskeleg å setje ord på eiga erfaring. Korleis kling ein tenorsaksofon? Enkelte erfaringar med verda kan ikkje artikulerast fullt ut, språkleg. Desse erfaringane som me ikkje fullt ut kan artikulere har i vitskapsteorien fått namnet taus kunnskap (Polanyi, 1966). For å kunne formidle lyden av eit instrument er det lettare å spele av eksempel på denne instrumentalklangen; ein er avhengig av sanseerfaring og rettleiing. Eksempla kan ikkje veljast vekk frå formidlinga, fordi eksempla er tydingskonstituerande for kunnskapen sin gyldigheit. ${ }^{3}$ Sagt på ein annan måte: våre omgrep om verda er forankra i visse

\footnotetext{
${ }^{1}$ Auditiv sonologi (AS) er utvikla gjennom 35 år av professor Lasse Thoresen med kollegaer ved Norges Musikkhøgskole. AS har vore nytta i komposisjonsundervisninga, men ikkje innan andre studieområde som til dømes improvisert musikk.

${ }^{2}$ Kombinasjonen Artist/Researcher/Teacher er ein eigen forskingsmetodologi som går under namnet $\mathrm{A} / \mathrm{r} /$ tography. Denne metodologien anerkjenner også den pedagogiske sida av utøvar/ forskar-dimensjonen. Metodologien har sine røter i canadisk akademia. Sjå: http://artography.edcp. educ.ubc.ca/?page_id=69

${ }^{3}$ Tolking av Ludvig Wittgenstein, attergjeven av Kjell S. Johannessen i føredraget «Wittgenstein og den tause kunnskapen", NMH, 6.-7. juni 2014. Original:Wittgenstein (1977: \317). Føredraget er samanfatta i teksten Tanker om taus kunnskap, intern publikasjon ved NMH. Sjå elles: Johannessen (1994), og Johannessen (2001).
} 
handlemåtar, og desse handlemåtane er difor ein del av omgrepet sitt meiningsinnhald. Om ein skal ta konsekvensen av dette, må ein altså kunne vise til dei klingande musikkeksempla når ein vil gjere greie for analysane ein gjer av musikken, noko som er vanskeleg i dei tradisjonelle bokformata og den tradisjonelle forskingsformidlinga. Her har nye fleirmediale uttrykk komme som ei redning, og blant anna har nye presentasjonsformer komme ut av arbeid i Stipendiatprogrammet for kunstnarleg utviklingsarbeid i Norge. ${ }^{4}$

Å forske på sin eigen praksis har ein lang tradisjon innan profesjonsutdanningane, men har dei siste åra også fått eit veldig oppsving innan kunstforsking gjennom eit eige omgrep kalla artistic research, på norsk ofte omsett til kunstnarleg utviklingsarbeid. ${ }^{5}$ Artistic research (AR) har utvikla seg parallelt i mange land etter at Bolognaerklæringa i 1999 gav høgskular og universitet ein felles struktur på utdanningane. Det vart då eit behov for å utvikle forskings- og doktorgradsprogram innanfor det som tidlegare hadde vore reine fagskular, som til dømes kunstutdanningane. Mange har sidan 90-talet skrive om, og utdjupa kva AR er og kan vera, og ulike tradisjonar har etablert seg både innanfor ulike fagfelt og ulike land. ${ }^{6}$

Artistic research er ikkje ein metode, men eit paraplyomgrep for fleire metodar, som i tillegg til nye typar av presentasjonsformer viser ein auka sjølvtillit på kunsten sine vegne i akademia.

Their [The Artists] absence has contributed to a situation that favoured the development of theoretical and historical constructs which, while shedding light on many complex and important issues, remained silent on significant aspects of musical and artistic reality, leaving out issues particularly relevant to artists. (Crispin, 2016, upublisert NMH-publikasjojn)

Artistic research har utfordra hegemoniet som humaniora og samfunnsvitskapane har hatt på å definere forsking på kunst, først og fremst ved å insistere på at det finst ein kunnskap om den utøvande praksisen som er delvis skjult for andre enn utøvaren, som best kan forskast på gjennom utøving og ved å organisere utøvande kunstnarar i forskarfellesskap, delvis på sida av akademia og delvis innanfor.

Avhengig av programmet ein forskar i, er det sjølve vegen frå denne opparbeida kunnskapen til formidlinga av den, som er utfordrande. Innanfor eit program med sterke føringar og sterke tradisjonar kan ein måtte kjempe heile vegen for sin forskarutøvar-autonomi. Innanfor eit program utan slike føringar og tradisjonar må ein sjølv orientere seg og velje blant alle mulege metodar.

${ }^{4}$ I Norge har Program for kunstnerisk utviklingsarbeid (PKU) hatt et stipendiatprogram (frå 2018 ein foreslått forskarskule) som kvalifiserer til førsteamanuensiskompetanse innan kunstnerisk utviklingsarbeid.

${ }^{5}$ Omgrepet kunstnarleg/kunstnerisk utviklingsarbeid forstås i Norge som ei grein av Artistic research, nytta av PKU og av ulike universitets- og høgskulemiljø med kunstfag.

${ }^{6}$ Viktige litteraturbidrag som har definert Artistic research for eksempel Borgdorff, (2011), Biggs \& Büchler (2011), Crispin, Coessens \& Douglas (2009), Frayling (1993), Hannula, Suoranta \& Vadén (2014) og Lilja (2015). 


\section{Frå forskingsspørsmål til auditiv sonologi som metode}

Utgangspunktet for forskingsprosjektet som står i fokus for denne artikkelen var mi erfaring/forventning om at musikarane i eit fritt improvisert samspel gir små teikn til kvarandre undervegs, og at desse små teikna kan forklare korleis me føregrip og vert einige om ei formutvikling som ingen veit om på førehand. Dette førte meg til omgrepet «gestar», og vidare til omgrepet «musikalske gestar». Denne leitinga etter ein farbar veg til forskinga, var den mest kritiske og frustrerande delen av forskinga. Etablerte akademiske omgrep er lada med gitte tydingar, bruksområde og historikk. God forskingsskikk seier at anten nyttar du omgrepet på den etablerte måten, eller så styrer du unna. Alternativt måtte eg finne opp mine eigne omgrep som ikkje sto i nokon vitskapsteoretisk tradisjon.

Auditiv sonologi var ein eksisterande metode som kunne hjelpe meg å svare på mange av dei spørsmåla eg stilte, og samstundes ta vare på nærleiken til den klingande musikken:

- Klanganalysane (spektermorfologiske analysar) ${ }^{7}$ viser korleis ein kan oppfatte den einskilde klangen som ein gest.

- Analysar av formdanning (nivå 3-analysar: sjå tabell 1) i auditiv sonologi gir eit større tidsbilete og syner samanhengen mellom klangeiningar og utvikling av større musikalske former, "gestaltar» - altså den samanhengen mellom små teikn og større former som eg var på leit etter.

- Grunnlaget for analysen er den innspelte musikken, som beheld sine materielle (her forstått som perseptible) eigenskapar, men som endrar meiningsinnhald gjennom ulike lytteintensjonar.

Ved å velje auditiv sonologianalyse valde eg å konsentrere meg om dei klanglege gestane i musikken. Dette var ikkje eit sjølvsagt val, sidan den improviserte musikken er så knytt til kropp og kroppsleg læring.

\section{Auditiv sonologi: lytting som analysemetode}

[...] it gave a model for mediation between music as parole, and music as langue; between temporal and sonorous unfolding and non-temporal, paradigmatic meaning. (Thoresen, 2015, s. 166)

Auditiv sonologi er utvikla av Lasse Thoresen og kollegaer, men hentar inspirasjon og mange omgrep frå det banebrytande arbeidet til Pierre Schaeffer og denne sitt arbeid med å granske $l y d .{ }^{8}$ Schaeffer prøvde å bryte ned den enkelte klangen til

\footnotetext{
${ }^{7}$ Vidare i artikkelen vil klanganalysar vera nemnde som spektermorfologiske analysar $=$ studie av klang og klangutvikling. Termen vart lansert av Dennis Smalley (1997) og er ein engelsk versjon av Pierre Schaeffer's (1977/1966) franske term 'typomorphologie'.

${ }^{8}$ Metoden byggjer på arbeidet til den franske komponisten, filosofen og musikkteoretikaren Pierre Schaeffer, og denne si kategorisering av klangtypar, Traité des objets musicaux (TOM) (1977/1966).
} 
sine delar, i eit forsøk på å finne klangen sine inste eigenskapar: Kva er ein klang? Korleis er ein klang bygd opp? Auditiv sonologi som metode er utvikla frå utøvaren, komponisten og lyttaren sin ståstad. Den er skapt ut frå eit ønskje om å rydde opp i den musikalske samtalen. Eit viktig steg i den analytiske prosessen er kravet om å klargjere sin eigen lytteintensjon; kva lyttar eg etter? Auditiv sonologi ber oss om å lytte til ulike lag i musikken, å velje ulike lytteintensjonar - som regel ein om gongen. Metoden gier bruk av tre vitskapsteoretiske retningar som kvar for seg har sterke tradisjonar: fenomenologi, semiotikk og hermeneutikk. Vel medviten om det paradoksale ved å analysere musikk, prøver metoden å finne balanse mellom desse til dels stridande teoretiske posisjonane. Thoresen på si side, ser mulegheita for ein metode som tek det beste frå ulike vitskaplege tradisjonar:

Thus what we propose is a synthesis: phenomenology informs our approach to listening intentions and object constitution while at the same time it helps us to avoid a reductionist perspective; elements of structuralism and semiotics serve to reveal the logical relationships between musical elements. Through the process of a hermeneutical exegesis involving repeated listening and tentative analyses, the analyst may eventually arrive at a condensed comprehension of essential features central to the musical work at hand. (Thoresen, 2015, s. xxviii)

Målet med metoden er å finne symbolske og strukturelle måtar for å kunne uttrykke musikalsk innsikt, men sidan den stadig blir prøvd ut i undervisning og gjennom diskusjonar med musikarar og komponistar, unngår den i følgje Thoresen å hamne i ein eigen mental sfære (Thoresen, 2015, s. 167).

I auditiv sonologi har «fonogrammet» erstatta "partituret» som kjelde for analytisk refleksjon. Ein god grunn til å bytte ut partituret til fordel for innspelt musikk som kjeldegrunnlag for den analytiske refleksjonen, er at svært mykje av dagens musikk, inkludert popmusikk og folkemusikk, ikkje vert arbeidd ut gjennom det mellomleddet som partituret er (Thoresen, 2015, s.170). Sidan den analytiske refleksjonsprosessen utviklar seg over tid, treng ein at objektet som er gjenstand for refleksjonen bevarast som eit stabilt, materielt medium som ein til stadigheit kan gå attende til, og som kan delast med andre. Auditiv sonologianalyse kan forståast som ein hermeneutisk prosess, der det at ein studerer ei musikalsk eining sine delar og sjikt, dannar grunnlag for ei djupare og rikare erfaring enn den første og kanskje overflatiske opplevinga av musikken.

\section{Lytting og minnearbeid}

Auditiv sonologi byggjer på ei erkjenning av at musikk er eit framveksande, emergent fenomen. Utan tid, ingen musikk, og utan rom, ingen klang. Sidan musikken er bunden av tida, er vår lytting til musikken avhengig av vårt minnesarbeid. Her og no kan me lytte til den einskilde klangen som står framfor oss. Ved hjelp av korttidsminnet kan me halde fast sekvensar av klangar slik at dei utgjer mønster som melodikk, harmonikk, rytmikk. Ved hjelp av vårt langtidsminne kan me «fryse» fast større former i minne vårt; oppleve 'setningar' og større sekvensar som form. 
Tabell 1. Artikulasjonsnivå i analysearbeidet.

\begin{tabular}{llll}
\hline Artikulasjon & Formål & Lytteintensjon & Minneprosess \\
\hline Nivå 1 & Analyse av klangobjekt & Reduktiv lytting & Ekkominne \\
Nivå 2 & Analyse av klangmønster & Taksonomisk lytting & Korttidsminne \\
Nivå 3 & Analyse av formdannande mønster & Taksonomisk lytting & Langtidsminne \\
\hline
\end{tabular}

The three memory processes just described (echoic memory, short-term memory and long-term memory) are related to three different time levels of musical experience, which I will refer to, respectively, as the «level of event fusion", "the level of melodic and rhythmic grouping», and the "level of musical form» [...] The three types of processing define three basic time scales on which musical events and patterns take place. (Snyder, 2000, s. 13f)

Dei tre omtala minneprosessane, omtalt i tabell 1, står altså i høve til tre ulike tidsnivå der musikalske hendingar og danning av mønster finn stad; heretter kalla «lyttenivå». Ei auditiv analyse bør difor artikulerast på desse tre ulike nivåa av lytting:

Nivå 1: Reduktiv lytting vil seie at ein prøver å høyre lyd som lyd. Ein prøver å frigjere seg frå andre lytteintensjonar, som «kva instrument», «kva stil», osb. Innan auditiv sonologi nyttar ein termen spektermorfologi for studiet av dei enkelte klangane. Spektermorfologi er sett saman av «spekter» (= spektrum, samling av einingar) og «morfologi». (= læra om form, endring i tid)

Nivå 2: Gruppering av klangobjekt i større gestaltar. ${ }^{9}$ Den taksonomiske lyttinga fokuserer på korleis musikk vert organisert innbyrdes i mønster, ofte med eit mål om å skape oversikt utan å gå for mykje i detaljar. Først på nivå 2 kan ein tala om «musikalsk lytting». (Thoresen, 2015. s. 16)

Nivå 3: Mønster sett saman av elementære klanggestaltar, og/eller av lange klangobjekt.

Frå lyttaren sitt perspektiv så heng artikulasjonen av dei tre nivåa saman med ei endring av fokus, og dermed ei endring av lytteintensjon. Etterkvart som artikulasjonen er gjenstand for nærare gransking, er det viktig å minne om kor samanhengande nivåa er. Musikken er ein integrert heilskap, men nivåa er del av noko som oppstår igjennom ei selektiv lytting fundert i ein analytisk praksis. I klangbasert musikk (det vil seie musikk som ikkje er intervallbasert) vil artikulasjon på nivå 1 og 2 vere vanskeleg å skilje. Ofte vil analysen av klangobjekt leie til eit aspekt av spektermorfologien, klangkarakterar. Klangkarakterar kan sjåast på som ein klasse av klanglege kvalitetar hjå ei samling av klangobjekt. ${ }^{10}$ Klangkarakterar vil danne ei bru til nivå 2. (Thoresen, 2015, s. 255)

${ }^{9}$ Ordet gestalt thas the meaning of a concrete individual and characteristic entity, existing as something detached and having a shape or form as one of its attributes [...] A gestalt is therefore a product of organization, organization the process that leads to a gestalt.» (Koffka, 1963/1935, s. 683) ${ }^{10}[\ldots]$ the term sound-character only refers to a class of timbral qualities (including the energetic profile of a sound-object) [...]. (Thoresen, 2015, s.71) 
Tabell 2. Thoresen sin framgangsmåte for auditiv sonologianalyse (Thoresen, 2015, s. 255). Sjå fotnote for forklaring av isotop ${ }^{11}$

Nivå 1 og 2:

1. Gjer ein spektermorfologisk transkripsjon, der ein bruker gitte kategoriar og symbol, gierne med ei forklaring av dei vala ein har teke.

2. Identifiser dei grunnleggande klangkarakterane og dei ulike "familiane»/einingane, desse utgjer, saman med variasjonane deira.

3. Diskuter likskapar og ulikskapar mellom klangkarakterane, og korleis dei relaterer til kvarandre.

4. Identifiser dei ulike spelverdiane til kvar klangkarakter: Korleis vert dei spelt med og utvikla?

På bakgrunn av dette kan ein starte å diskutere ulike aspekt av form:

Nivå 3:

5. Identifiser tidsfelt (segment) og/eller sjiktstrukturen til stykket.

6. Utvikle ei hypotese for den relevante formbyggande isotopen til stykket og avgjer kva analytiske reiskap du vil nytte vidare: formbyggande prosess [gjentaking, variasjon, kontrast], formbyggande funksjonar [t.d. dynamisk form], formbyggande transformasjonar [t.d. frå enkel til kompleks form].

\section{Bruk av metoden}

Thoresen vil at analysemetoden skal utøvast med stor kreativ fridom og at den kan tilpassast individuelle tilhøve og ulik bruk. Men han understrekar at ein samstundes må læra bruken av analysemetoden; at den er ei ferdigheit som skal trenast på. I tillegg kjem kravet om at metoden skal kunne vera transparent; den skal danne utgangspunkt for ein diskusjon med andre forskarar og utøvarar om $k v a$ ein høyrer. Eit viktig mål med denne auditive analysemetoden er at både den som analyserar og den som les analysen skal ha oppdaga og retta merksemda mot dei same auditive dimensjonane i det ein høyrer. Dette legg eit ansvar på den som skriv analysen om å klargjere kva nivå i lyttinga det er snakk om. Thoresen føreskriv ein framgangsmåte som skal rettleie den som gjer analysane. For meg som var ukjent med analysemetoden, var det viktig å følgje denne framgangsmåten så godt eg kunne i byrininga. Først her kjem Thoresen si «oppskrift» (Thoresen, 2015, s 255), deretter med mine dømer. Alle dømer er henta frå mi avhandling (Ølnes, 2016).

Alle stega i tabell 2 er basert på det som er gitt auditivt. Det inneber at analysane utelet det Thoresen kallar ei eksosemantisk forståing av musikken (t.d. av ein gest): den tydinga som refererer til / peikar på noko anna, utanfor musikken.

I mitt arbeid har jeg utviklet Thoresens metode slik: ${ }^{12}$

\section{Nivå 1 og 2}

${ }^{11}[\ldots]$ the isotopy represents a principle ensuring coherence among diversified elements; [...] (Thoresen, 2015, s. 215).

${ }^{12}$ Skissene i kap. 2.2. er bileter av analysane, utan lydeksempel. 


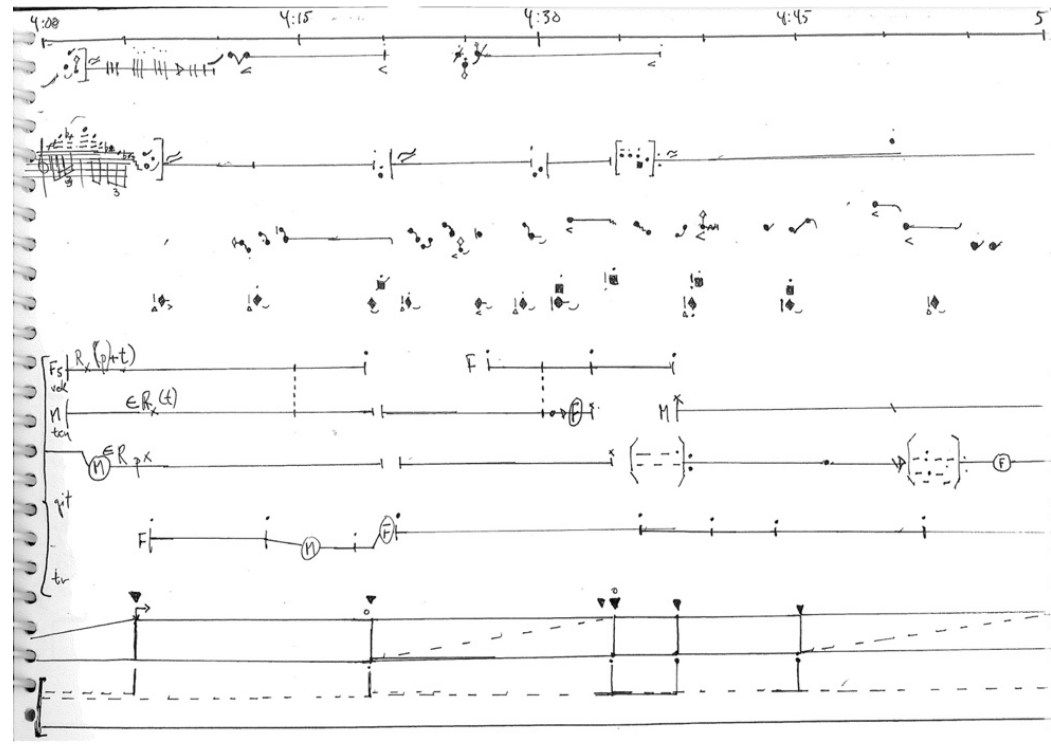

Figur 1. Frå skissearbeidet mitt med sonologianalysen.

1. Gjer ein spektermorfologisk transkripsjon, med bruk av gitte kategoriar og symbol. ${ }^{13}$

Eg analyserte 16 minutt med BMX-improvisasjon. Musikken var delvis intervallbasert og delvis klangbasert, difor nytta eg enkelte stader notelinjer og «vanleg» notasjon inni typologien til Thoresen. Eg gjorde greie for vala eg tok, som til dømes separeringa av musikken til fire stemmer. Seinare drog eg saman klanganalysane på nivå $1 \mathrm{og}$ formanalysane på nivå 3 på eit stort skisseark, der eitt ark representerte eitt minutt med musikk (sjå Figur 1).

2. Identifiser grunnleggande klangkarakterar og dei ulike «familiane» desse utgjer, saman med variasjonane deira.

Analysen min synte ulike grupper av klangkarakterar, ulike måtar spelarane nyttar desse i spelet sitt, og korleis dette spelet skapar interaksjon i gruppa som påverkar den totale formutviklinga. Analysen vart komplettert med sitat frå BMX-intervjua (Figur 2). I eksemplet under står A for ein tonal klangkarakter, medan A3 og A4 her er spesielle underklassar av den tonale klangkarakteren.

3. Diskuter likskapar og ulikskapar mellom klangkarakterane, og korleis dei relaterer til kvarandre.

\footnotetext{
${ }^{13}$ For meir innsikt og oversikt bør lesaren studere kapittel 4 i Emergent Musical Forms (Thoresen, 2015), eller gå til nettstaden www.auralsonology.com, meir spesifikk URL: http://www.auralsonology.com/the-signs/chapter-4-spectromorphology/ http://www.auralsonology.com/the-signs/chapter-6-time-fields/ Ei samanfatting av Thoresen sin typologi med norske nemningar og omgrep finnast i kapittel 6-8 i (Ølnes, 2016, s. 81-92, 118-125 og 140-147) og kan lastast ned gratis frå https://brage.bibsys.no/xmlui/handle/11250/2381966
} 


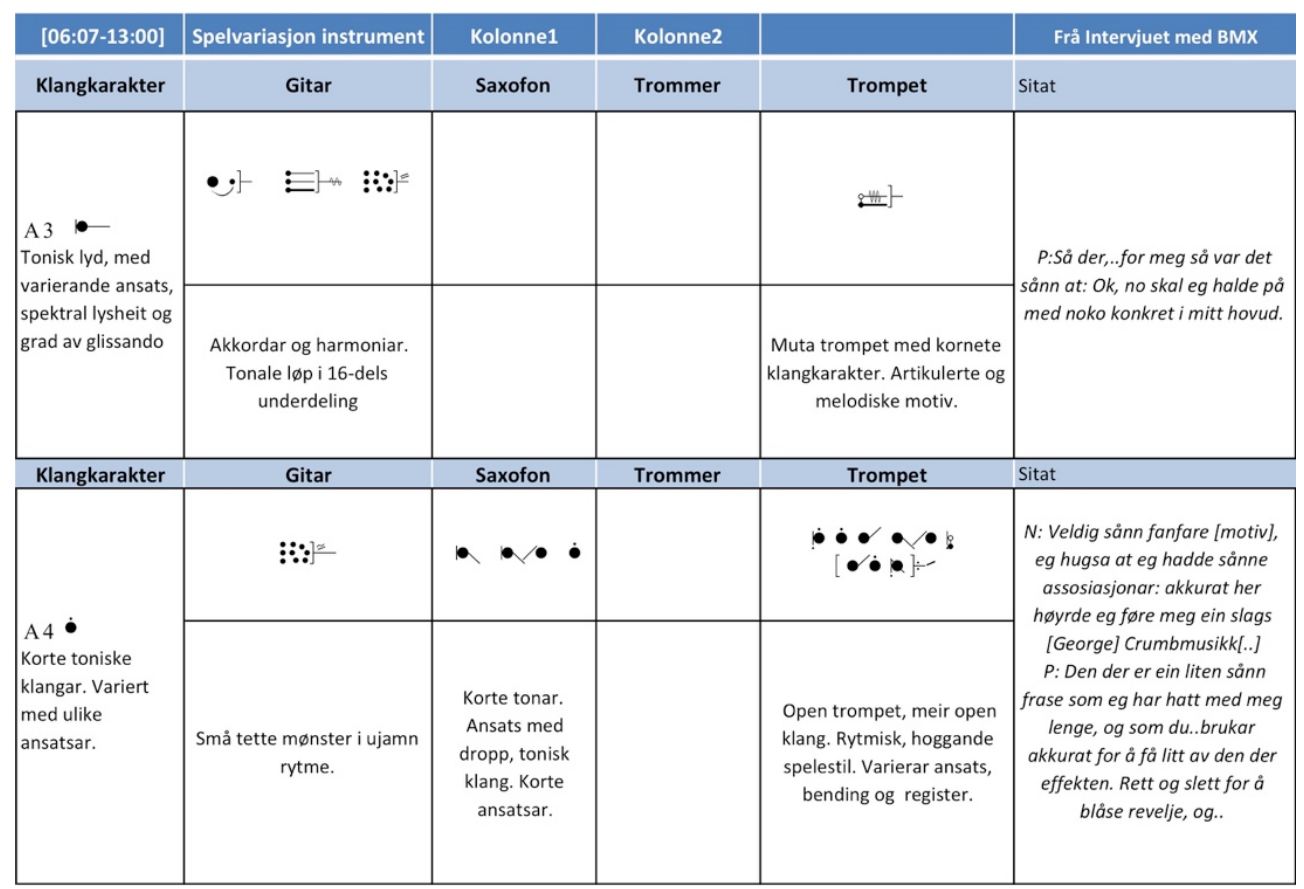

Figur 2. Utdrag frå tabell over klangkarakterar. Lydspora er her tatt bort. For full attergjeving, sjå (og høyr) Ølnes (2016, s. 98-100).

Klangkarakteren er altså viktig for utviklinga av improvisasjonen. Kva er det som kan utviklast? Kva former for utvikling kan skje?

I. Lineær utvikling av klangkarakter gjennom variasjon og utviding av klangkarakter [0:05-2:35].

II. Lineær utvikling gjennom utbrodering og herming av klangkarakter [9:48-].

III. Lineær utvikling gjennom komplementaritet $\mathrm{i}$ bruken av klangkarakterar:

$$
\begin{aligned}
& \text { opp/ned [2:37-4:00] } \\
& \text { sterk/svak [4:40-] } \\
& \text { intens/roleg [4:22-] } \\
& \text { kompleks/enkel [7:38-] }
\end{aligned}
$$

IV. Utvikling gjennom brot og plutselege skifte av klangkarakter [4:08].

V. Utvikling gjennom delvis skifte og delvis utvikling av alt innførte klangkarakterar [10:40].

I intervallbasert musikk vil høve mellom form og klangkarakter spela ei underordna rolle.

I ein improvisasjon av BMX vil musikken skifte mellom intervallbasert og klangbasert, slik at graden av kor mykje klangkarakteren har å seie for forma og utviklinga i improvisasjonen vil skifte med dette.

Figur 3. Utdrag frå diskusjon om klangkarakterar. 


\section{N. Ølnes}

Dette punktet er delvis svara for i analysane som er referert til i fig. 2, men i tillegg utvikla eg denne delen av analysen til ein diskusjon av samanhengen mellom bruken av klangkarakterar og formutvikling i samspelet: Kva fører desse like og ulike klangkarakterane til i samspelet? Korleis påverkar val av klangkarakterar sjølve det improviserte spelet?

4. Identifiser dei ulike spelverdiane til kvar klangkarakter: Korleis vert dei spelt med og utvikla?

Figur 4 under syner utvikling av ein felles tonisk klangkarakter i starten av improvisasjonen og korleis dette la grunnlaget for formbygginga.

På bakgrunn av dette kan ein diskutere ulike aspekt av form.

\section{Nivå 3}

5. Identifiser tidsfelt (segment) og/eller sjiktstrukturen til stykket (sjå skisse i fig. 1).

6. Avgjere kva analytiske reiskap du vil nytte vidare: formbyggande prosessar, formbyggande funksjonar, formbyggande transformasjonar.

Her valde eg å gjere dynamisk formanalyse, form- og transformasjonsanalyse, samt sjiktanalyse. ${ }^{14}$

7. Lag ei liste av dei viktigaste klanghendingane: Karakteristiske gestar, gjentakande hendingar, intense eller «spesielle» augneblinkar.

\begin{tabular}{|c|c|c|c|c|c|c|c|c|c|}
\hline Tid & 00:05 & $00: 15$ & $00: 27$ & $00: 42$ & 01:22 & 01:28 & 01:37 & 01:58 & 02:10 \\
\hline Klangkarakter & $\bullet$ & on & $\diamond \bullet$ & $\bullet$ & $\vdots-$ & - & $a-1$ & $\bullet-1$ & 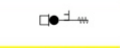 \\
\hline Instrument & Vokal & Gitar & Saksofon & Gitar & Gitar & Vokal & vokal & saksofon & Vokal \\
\hline $\begin{array}{l}\text { Innføring av nye } \\
\text { klangelement på } \\
\text { tonisk klang }\end{array}$ & $\begin{array}{l}\text { Tonisk, utan } \\
\text { attakk. Mørk }\end{array}$ & $\begin{array}{l}\text { Utan attakk, } \\
\text { med litt } \\
\text { vibrato }\end{array}$ & $\begin{array}{l}\text { Luft før tonen } \\
\text { kjem, litt } \\
\text { vibrato }\end{array}$ & $\begin{array}{c}\text { Skiftar } \\
\text { tone/pitch }\end{array}$ & $\begin{array}{l}\text { Fleirstemt/ } \\
\text { harmoniar }\end{array}$ & $\begin{array}{c}\text { Med attakk og } \\
\text { dropp og } \\
\text { vibrato }\end{array}$ & $\begin{array}{l}\text { Skiftar til } \\
\text { lysare } \\
\text { klangfarge. } \\
\text { Glidande }\end{array}$ & $\begin{array}{l}\text { Crescendo/ } \\
\text { decrescendo }\end{array}$ & $\begin{array}{c}\text { Sterkt "mage"- } \\
\text { ansats, med } \\
\text { sterk vibrato }\end{array}$ \\
\hline $\overrightarrow{-}=$ liniær utv. & $\rightarrow$ & $\rightarrow$ & $\rightarrow$ & $\rightarrow$ & $\rightarrow$ & $\rightarrow$ & $\rightarrow$ & $\rightarrow$ & \\
\hline
\end{tabular}

Figur 4. Utdrag frå korleis klangkarakterar vart utvikla over tid. Lydspora er her tatt bort. For full attergjeving av analyse, sjå Ølnes (2016, s.103-105).

\footnotetext{
${ }^{14}$ For typologi av sjiktanalyse, dynamisk formanalyse og analyse formdannande transformasjonar, sjå spesifikt: http://www.auralsonology.com/the-signs/chapter-7-layers/ og http://www.auralsonology.com/the-signs/chapter-8-dynamic-forms/ og http://www.auralsonology.com/the-signs/ chapter-9-form-building-transformations/ (tilgang 14.10.2017)
} 

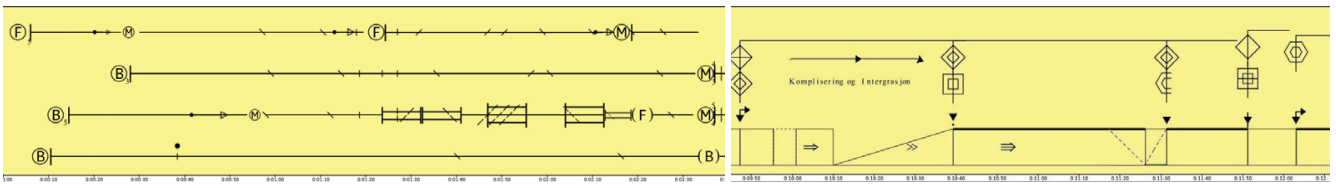

Figur 5. A: Utdrag frå sjiktanalyse, frå starten av dei 16 minutta. B: Utdrag frå dynamisk form- og transformasjonsanalyse. ${ }^{15}$ For video med lydspor, sjå Figur 8 og 9.

Tabell 3. Eit utdrag frå lista over viktige augneblinkar, karakteristiske gestar i BMX-improvisasjonen. For full attergjeving med lydeksempel, sjå/høyr Ølnes (2016, s. 237)

\begin{tabular}{llll}
\hline Døme & $\begin{array}{l}\text { Dynamisk } \\
\text { formanalyse }\end{array}$ & $\begin{array}{l}\text { Transformasjon } \\
\text { sanalyse }\end{array}$ & Sjiktanalyse \\
\hline $\mathrm{B}[04: 38]$ & & $\begin{array}{l}\text { Ktløysande punkt: plutseleg } \\
\text { skifte av energi og form, set } \\
\text { ny puls og tonalitet. }\end{array}$ \\
$\mathrm{C}[11: 47]$ & & $\begin{array}{l}\text { Samlande punkt: tilfører } \\
\text { pregnans og set ein ny } \\
\text { tonalitet. }\end{array}$
\end{tabular}

Her er dømer på viktige klanghendingar/augneblinkar i musikken som er analysert, fanga opp i dei ulike analysane:

I denne samanstillinga har eg sett høgdepunkt viktige augneblinkar gjennom alle analysane eg gjorde på nivå 3. Slik har eg fått eit fleirspektra bilete på desse hendingane.

\section{Innsirkling og metodologiske refleksjonar}

Kva skal ein undersøke og korleis? Dette enkle spørsmålet kan gi ein forskar store kvalar. Ein lyt skjere gjennom og velje eksempel som svarer på forskingsspørsmåla. I mitt tilfelle skjedde utveljinga som ein kombinasjon av tilfeldigheiter og veksande klarheit om kva eg ville med materialet.

\footnotetext{
${ }^{15}$ Analysane er gjort i programmet Acousmographe, med fonttypen Sonova. L'Acousmograph er eit reiskap for analyse og presentasjon av elektroakustisk musikk, utvikla av INA-GRM, Paris. Den let ein få lage grafiske framstillingar og tekstmerknader synkronisert med å lytte til representasjonar av (musikk) signalet (kalla spektralanalyse).
} 


\section{Utval av empirisk materiale}

Ramma for å samle inn det empiriske materialet eg valde, var ein fem dagars turné på Vestlandet. Det musikalske klippet eg til slutt la til grunn for ei grundig auditiv analyse, var 16 minutt frå ein konsert på Kabuso-museet i Øystese, valt av både praktiske og kunstnarlege grunnar:

- Det var den siste av fire konsertar på rad.

- Lyttetilhøva var framifrå, noko som gjorde at me spelte tilnærma akustisk og ikkje var avhengig av lydteknikar.

- Konserten fann stad i ein eigen konsertsal, ikkje ein jazzklubb der ein må avbryte praten for å få merksemda, noko som gav oss heile regien på konserten.

- Grunna dei gode lyttetilhøva kunne me utnytte dynamikken til fulle, slik at utsnittet fekk med mange dimensjonar av samspelet i BMX.

- Dei 16 minutta frå starten av konserten utgjorde ein logisk heilskap, sjølv om dette var ein fri improvisasjon der ingen ting var avtalt - eit avgjerande poeng i høve forskinga.

Nokre problem med å bruke akkurat dette utsnittet:

- Stereomikrofonane som skulle garantere god lyd, viste seg å ta opp temmeleg ubalansert, samanlikna med samklangen me sjølve oppfatta på konserten. Eg valde difor å bruke den komprimerte kameralyden, noko som gav litt redusert klangkvalitet, men betre balanse mellom dei ulike instrumenta.

- Utsnittet syner ikkje korleis me responderte på ulike lokalar og ulikt publikum. Ved å ta smakebitar frå alle konsertane kunne eg ha undersøkt korleis lyttetilhøve og interaksjon med publikum påverkar formskapinga til bandet.

[...] eg berre anar at dette var eit veldig godt rom å vera i, altså, at rommet er ein slik faktor, som du kanskje ikkje får heilt tydeleg i eit så lite utsnitt. Men det hugsar eg, den fornemmelsen, at vi blei ståande så lenge i den modusen som vi gjer i starten der. Det er nok fordi i rommet, det gir meining i rommet meir enn om vi hadde gjort det ein annan stad. (sitat musikar-forskingsdeltakar i Ølnes, 2016, appendiks s. i).

Framgangsmåtar og etiske perspektiv knytt til medspelarane si involvering i forskinga Det var avgjerande for meg at musikarane i BMX skulle ha ei stemme inn i forskinga, utover det reint musikalske materialet dei bidrog med. Men korleis skulle eg ta vare på deira individuelle kunnskap om samspelet? Dette er ei kjent problemstilling frå antropologien og andre samfunnsvitskapar. I kva grad bør dei som er forska på kunne få uttale seg om forskinga? På den eine sida må forskaren få vera fri til å gjere observasjonar og refleksjonar utan å måtte binde seg for mykje til andre personar og grupper. På den andre sida gjeld god forskingsetikk: å handsame deltakarane i forskinga med respekt, som kollegaer meir enn som forskingsobjekt; å skrive på eit språk deltakarane forstår; å vera klar over makta ein har som forskar; å prøve å sameine den akademiske verda med den røyndomen som er undersøkt (Ndimande, 2012 i Kara, 2015, s. 43).

For meg var det også avgjerande at me skulle vera reflekterande saman som gruppe, for å styrke vår kollektive kunnskap rundt samspelet og utvide medvitet om 
kvarandre sine handlemåtar. Dette var avgjerande for å få kunstnarleg utkomme av forskinga, noko som var ein motivasjon for i det heile teke å forske på det improviserte samspelet. Eg valde to framgangsmåtar:

Under heile turneen sette eg av tid før konsertane til ein samtale, der me snakka om konserten i går, og om forventingane til kveldens konsert. Samtalen kunne vare frå 15-40 minutt, og var ei fin anledning til å komme nærare inn på kvarandre sine intensjonar og tankar rundt spelinga. Kva hadde me sett føre oss i går? Kvifor gjorde me enkelte val undervegs, var dei medvitne eller ikkje? Det at eg sette eit kamera framfor oss gjorde også praten meir konsentrert og høgtideleg enn ein vanleg garderobeprat - det la til rette for kontinuerleg refleksjon i gruppa.

Den andre framgangsmåten vaks ut frå behovet for ein konkretiserande samtale kring det utsnittet eg hadde valt for analyse. Eg kom ikkje i gang med analysearbeidet før eit halvår etter turneen, og ni månader etter konserten samla eg musikarane i BMX til ein samtale om utsnittet. Dette vart gjort etter modell av det som vert kalla stimulated recall: Først høyrde me taust igjennom musikken saman, 16 minutt til ende. Deretter spelte eg det igjen frå starten, og alle kunne bryte inn og kommentere når dei hadde lyst. Då stoppa eg avspelinga og let samtalen gå fritt. Når alle hadde fått sagt sitt, sette eg i gang opptaket igjen, fram til neste avbrot. Me høyrde gjennom dei 16 minutta tre gonger og brukte totalt tre timar på å reflektere, diskutere og atterskape konserten me hadde helde for ni månader sidan. I denne økta bidrog musikarane i BMX aktivt som medforskarar. Deretter transkriberte eg samtalen vår, og let delar av den kommentere undervegs i analysane (jfr. Ølnes, 2016, s. 99).

\section{Funn gjort gjennom auditiv sonologianalyse}

\section{Spektermorfologi: Studiet av klang og klangutvikling}

Saksofonen kjennes som ein del av kroppen, ei forlenging. Eg syng gjennom saksofonen; ikkje med mine eigne stemmeband, men gjennom saksofonen sitt «stemmeband». Sidan eg ikkje veit heilt kvar eg skal i denne frie improvisasjonen, er klangomgjevnaden viktig for retninga; det eg høyrer i meg, giennom meg og rundt meg bestemmer dei musikalske vala vidare. (Mine refleksjonar)

Analysen av improvisasjonen sin første del synte at bandet kan forme klangkarakterar saman. Klangkarakteren som først vert lansert, vert vidareutvikla av bandet kollektivt. Nye kvalitetar og endringar vert lagt til klangkarakteren i fellesskap, og spelet får ein drodlande, spinnande karakter. Ein enkel, vibratolaus tonisk klang vert tilsett vibrato, ulike ansatsar, skiftande klangspekter, skiftande dynamikk, tillagt harmoniar og harmoniske funksjonar. Det enkle, toniske klangobjektet veks til ei samanhengande musikalsk form; ein enkeltklang utviklar seg gjennom dette kollektive spelet til ein full koraldel (sjå Figur 4 og Figur 8).

Spelet kan også ta form av brot og total utskifting av klangkarakterane. Analysen viser korleis ein av spelarane, vokalisten/perkusjonisten, endrar retninga på samspelet på ein augneblink med å lansere heilt nye, divergente klangkarakterar. Ca. 4 minuttar ut $\mathrm{i}$ improvisasjonen introduserer han ein slags kadens som bryt veldig med det som 


\section{N. Ølnes}

har vore. Sjå den spektermorfologiske analysen ${ }^{16}$ av «brot» som viser korleis bandet kastar seg rundt, fangar opp dei nye, ulike klangkarakterane i kadensen (Figur 6) og set dei i spel med ein gong. Slike raske skift kjem når bandet har hatt ei forventing om at noko snart skal skje, at den forma dei er inne i, er ved vegs ende. Dette underbyggast gjennom intervjuet med vokalisten (Ølnes, 2016, appendiks vi):

[...]. Det er akkurat som at det bygger seg opp ..., viss det har vore veldig lenge nokre element og så utelatt nokre andre musikalske element, så bygger det seg opp eit sakn eller eit behov som gier at det kjem noko meir ...

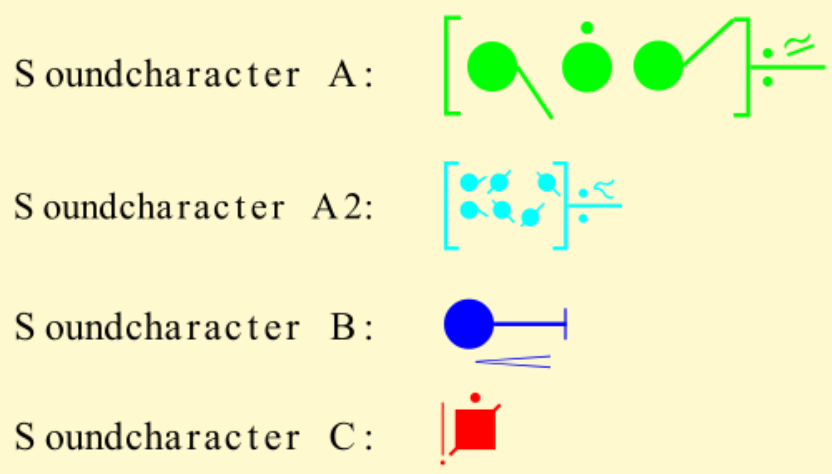

Figur 6. Syner dei klangkarakterane som vokalisten/perkusjonisten presenterer i sin kadens.

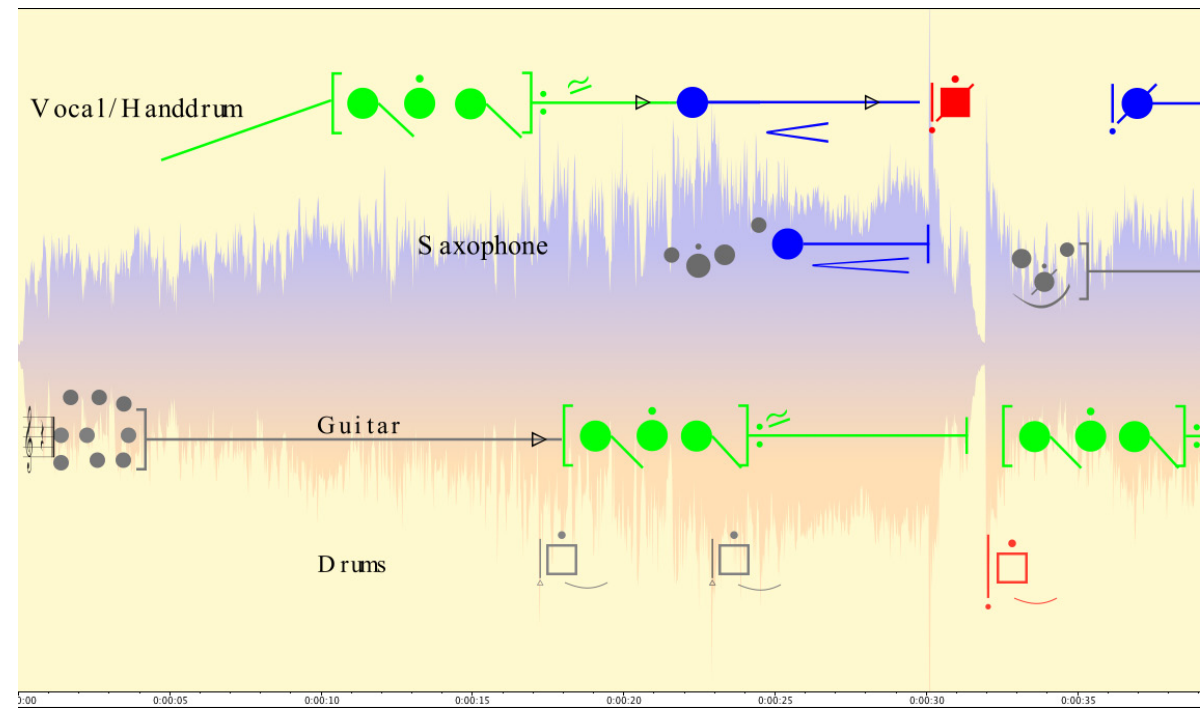

Figur 7. Syner korleis klangkarakterane presentert av vokalist/perkusjonist (her nemnt som vokal/ tromme), vert distribuert og sett i spel.

${ }^{16} \mathrm{https}: / /$ vimeo.com/222394527/4a0468be59 (tilgang 14.10.2017) 


\section{Emergente musikalske former}

Av og til kan eg kjenne på fragmentering og usikkerheit i bandet; ingen vil ta kommandoen, eg kjenner at eg står heilt åleine, og nøler: «kvar skal me?» Andre gonger kjennest vala opplagde; me vert spela av musikken, ingenting kunne vore annleis! $\mathrm{Og}$ atter andre gonger kan eg kjenne motstand mot å gå dit eg merkar dei andre vil. «Her har me vore før, dette er ein repetisjon!» Me er skapande i augneblinken, men under ligg det lag på lag med tidlegare erfaringar og musikalske reiser me har gjort saman. (Mine refleksjonar)

Emergente former oppstår konkret gjennom klangane si utvikling i tid. Dei kjem til syne, utan at dei er planlagde. Desse emergente formene er eit resultat av vårt minnesarbeid: der og då, når me høyrer musikken falde seg ut, høyrer me den i lys av fortetta minner om musikken som var, og med forventingar om det som skal komme. Til grunn for inndelinga av formsegment ligg det som kallast setningsstruktur eller tidsfelt. Det kan finnast eit hierarki av setningar, frå dei aller lengste som kan omfatte nesten heile improvisasjonen, til dei minste som nærmar seg små motiv. Dynamiske formelement er dei kreftene som gir oppleving av rettaheit og retning i musikken. Analysane viser at dei dynamiske formelementa følgjer tidsfelta, og at dei ofte understøttar formdannande transformasjonar.

Samspelet mellom dynamiske formelement og formtransformasjonar kjem aller tydelegast fram i første del av improvisasjonen. ${ }^{17}$ Der vert høgdepunktet i koralen nådd gjennom at spelarane tilfører musikken energi og framdrift ved bruk av små crescendoar, leietonar og ein tydelegare artikulasjon av melodiske motiv (Figur 8 og video i fotnote 17).

Analysen av dei 16 minutta viser at formtransformasjonane skjer kontinuerleg, at passasjane frå eit stadium til eit anna skjer på ein lineær måte. Den frie improvisasjonen spinner trådar, faldar seg ut i tida, den kan vanskeleg gå attende til tidlegare motiv og delar, ettersom slikt ikkje avtalast på førehand. Formanalysane av utsnittet viser at bandet brukar heile skalaen frå enkle til komplekse formelement, men at endringane tek tid: ein må bygge opp naudsynt mengde energi for å nå det mest komplekse stadiet, der eit meir kollektivt spel gjer at dei ulike instrumenta er vanskeleg å skilje frå

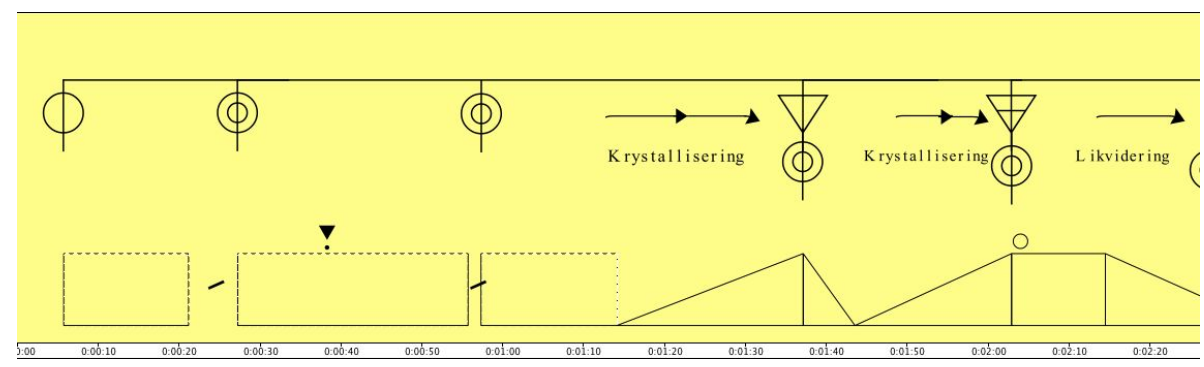

Figur 8. Dynamisk form- og transformasjonsanalyse. Frå starten av improvisasjonen.

${ }^{17} \mathrm{https}: / /$ vimeo.com/222395836/b428c13f3e (tilgang 14.10.2017) 


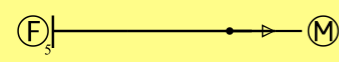

(B) ${ }_{3}$

\section{(B) 5}

(M)

(B)

5.00

Figur 9. Utdrag frå sjiktanalysen: vokalist/trompetist øvste lina, deretter saksofon, gitar og trommer nedst.

kvarandre, og der einskilde musikalske gestar kjem så tett at det opplevast som eitt instrument.

Sjiktanalysen (Figur 9) syner fram den soniske grunnveven med sin tekstur og sine mønster. Der ser ein framgrunns- og bakgrunnsperspektiv, samt synkrone og diagonale relasjonar mellom sjikta. Ved å sjå på sjiktanalysen ser ein kven som tek framgrunn og bakgrunn, og alliansane i samspelet. Det er først og fremst denne analysen eg har lagt til grunn når eg har undersøkt dei ulike samspelsfunksjonane eg har kalla rollar. $^{18}$

\section{Rollar og samspelsfunksjonar}

Analysane synte at eg i ulike improvisasjonar ofte tok rollen som vevar. Og ja, enkelte gonger kjennest det som eg sit inne i ein musikalsk vev. Eg strekker ut trådar, tek imot andre trådar, knyter saman og skapar ein heilskap. Dette høyrest ut som ein metafor for spelinga, men eg kjenner det òg fysisk, at musikken er trådar me slenger til kvarandre og set i saman. Iblant har eg vanskar med å lausrive meg; eg sit fast i veven og veit ikkje korleis eg skal slutte, endre, komme laus. Då treng eg at nokon kastar ei musikalsk line til meg utanfrå; nokon som dreg meg ut or veven. (Mine refleksjonar)

Dei ulike grunnposisjonane/relasjonane spelarane tek i samspelet indikerer noko som minner om «rollar». Ved å sjå det improviserte samspelet som samspelsfunksjonar og posisjonar kan ein fange opp dei ulike spelarane sine intensjonar i samspelet. Rollane (tabell 4) syner korleis spelarane søker å utfylla kvarandre på ulike kreative og føregripande måtar, dei syner intensjon over tid, langsiktig tidshorisont i musikken. Dei er mangesidige og muleg å gå inn og ut av, er ikkje «psykologiserande» eller knytt til spelarane som personar (sjølv om dei heng saman med personlege føresetnader). Dei er performative posisjonar ein kan velje i samspelet, mulege relasjonar ein kan ta til dei andre spelarane.

Gjennom å ta ulike rollar kan spelarane fullbyrde musikalske gestaltar som dei aner at er på gang - eller dei kan endre samspelet radikalt ved til dømes å ta rolla som sporvekslar, ein som brått endrar retninga i musikken. Rollane forklarar òg korleis dei

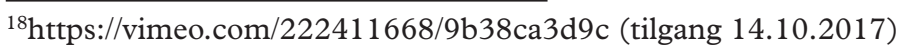


Tabell 4. Oversikt over dei ulike performative rollane eg artikulerte $\mathrm{i}$ analysen av samspelet til BMX.

\begin{tabular}{ll}
\hline Rolle & Beskriving av rolle \\
\hline Sporvekslar & Kan raskt skifte retning i musikken. \\
Leiar/førar & Tek framgrunn, fører an, syner veg. \\
Idéplukkar & Plukkar opp idear frå andre, følgjer opp utspel. \\
Vevar & Nøstar saman ulike idear, knyter saman, strekker ut. \\
Orkestrator & Fargelegger, klanglegger, tenkjer motstemmer/kontrapunkt, bruk av register m.m. \\
& Skapar både tekstur og gestur. \\
Rival & Utfordrar leiarrolla i kamp om framgrunnen, som tek plass i ein alt dekka framgrunn. \\
Rammemakar & Kan ramme inn musikalske setningar, slutte forma. \\
Strateg & Med vilje og evne til å skape langsiktig form, kontinuitet. \\
Det fleirhova trollet & Bandet som eit kollektiv, ei utfyllande rolle, mange stemmer \\
\hline
\end{tabular}

små gestane kan føre fram til større musikalske gestaltar. Om ein ser berre på einskilde klanglege gestar, ser ein at dei gjennom grad av rørsle, energi og artikulasjon skapar framgrunns- og bakgrunnsrelasjonar i musikken og mellom spelarane. Val av klangkarakter seier også noko om kva alliansar ein er ute etter i samspelet, eventuelt at ein vil ligge uavhengig i sitt eige sjikt. Intensjonar i spelet vert kommunisert anten gjennom endrande eller støttande gestar. For å endre retning, kontrastere eller skape brot i musikken, må ein lansere klangkarakterar som evnar å stå radikalt ut frå dei andre, og dei må verte presentert distinkt, vera vel artikulert og insisterande i spelemåten. For å støtte opp om, bygge vidare på eller utvide dei alt eksisterande klangkarakterane i musikken, må ein kunne røre seg lett mellom ulike tonalitetar, blande seg med eksisterande klangar og ha mulegheit for å utvikle spelet med desse.

\section{Det formande lyttearbeidet}

Her til slutt vil eg vende attende til forskingsspørsmålet: Korleis kan bruk av auditiv sonologi som analysereiskap hjelpe ein musikar-forskar til å forske på musikk innanfrå sin eigen kunstnarlege praksis? I det følgjande vil eg prøve å drøfte spørsmålet med bakgrunn i analysane i denne artikkelen.

\section{Kritiske merknader}

I min presentasjon av auditiv sonologi har eg framheva det eg har opplevd som positivt og frigjerande med denne metoden. Men den har sjølvsagt manglar, eller rettare sagt, den utelet viktige sider av det me forstår som ei heilskapleg musikalsk oppleving. Dette legg ikkje Thoresen skjul på:

Our research is focused on the perceived patterns of music-as-heard, thus finding itself within the limitations of a taxonomic approach to listening. Musical experience is of course potentially much more: feeling, ecstasy, mystery. (Thoresen, 2015, s. $\mathrm{xxx}$ ) 
Det ligg ein fare i å skape ei verd av logiske symbol basert på «etterpåklokskap». Sjølv om Thoresen understreka at auditiv sonologi er ein deskriptiv analysemetode, har historia synt oss at vegen til normative påstandar er kort. I det ein har skapt sine analysar, kan framstillinga bli sjølvforklarande: «ein høyrer det ein ser». Ei slik tilverking av røyndomen etter modellar er ei vanleg felle å gå i innan vitskapen. Medisinen er som alltid: ei audmjuk haldning og openheit for andre sine innspel.

Auditiv sonologi sin styrke kan òg bli denne sin svakheit: Den visuelle framstillinga av musikken, som hjå Thoresen har fått eit romleg og intuitivt preg, gjer at det vert fristande å diskutere bileta, heller enn lydopptaket. Tidsskrift og fagbøker favori-serer fortsatt tekst og bilete framfor lyd. Den påstått auditive tilnærminga vert då eit skalkeskjul for kanskje endå meir abstrakt tolking enn i tradisjonell musikkvitskap.

Det musikalske aspektet eg har sakna mest ved auditiv sonologi, er den kroppslege, pulserande sida av musikken. Musikk generelt og jazzmusikk spesielt, er fundert i ulike former for puls som kan ha større resonans i andre delar av kroppen enn øyra. Dette samspelet mellom puls, rytmikk, rørsle og form vert berre indirekte fanga opp i auditive analysar. Dei får med seg ansatsar, grupperingar og mønster, men ikkje den dimensjonen som spel med rytme og puls har i det fysiske rommet og på den fysiske kroppen. På ein konsert skjer ei synkronisering mellom rørsler og kroppar, som vil bli borte i eit lydopptak.

Ein kan få inntrykk av at auditiv sonologi skapar eit fragmentarisk syn på musikk, der ein skal identifisere objekt, ikkje sjå musikken som ein prosess. Ein del av omgrepa, som lydobjekt og reduktiv lytting, kan peike i den retninga. Men eg vil i det følgjande argumentere for at det nettopp er den musikalske prosessen ein får ei større innsikt i, gjennom dei auditive analysane.

\section{Jazz, intuisjon og skapande lytting}

"We are what we hear". (Horowitz, 2012)

Auditiv sonologi er ei form for konsentrert lytting til bestemte sider av musikken. «Beskriv klangkarakterane», «beskriv formdanninga», «beskriv dynamikken». På eit vis minner dette om korleis ein tradisjonelt har lært seg å spele jazzmusikk: gjennom nitid, repeterande lytting til førebileter på plater. Gjennom stadig betre konkretisering av kva ein høyrer, får ein med seg stadig fleire nyansar av spelet. I veksling med utøving på eiget instrument vil gehøret ein opparbeider vera kartet, eller «den indre stemma", som guidar ein i spelet. Dette er eit praktisk, lyttande arbeid, og ved å imitere det ein høyrer, får ein indirekte førestillingar av formene musikken er bygd rundt.

I den auditive sonologien lyttar ein medvitent etter større formsegment og formtransformasjonar. Det tradisjonelle imitasjonsarbeidet i jazzen har ikkje nytta dette «fugleperspektivet». Men det kan vera bra for improvisasjonsmusikaren å verte medviten om formoppbygging og større musikalske segment, å kunne lytte med større tidshorisont. Spesielt no, når den improviserte musikken forlèt dei tradisjonelle 
formene og gir seg i kast med klangimprovisasjonar, vil denne evna til å betrakte større formelement kunne vera til hjelp for å navigere musikalsk. Det ligg naturleg i (fri) improvisasjon å ha kort tidshorisont i lyttinga. Dess fleire musikalske hendingar som skjer rundt deg, dess meir automatisert vert spelet. Friimprovisasjon er impulsstyrt, spontant og intuitivt, men som Kahneman (2011) har synt, kan me ikkje stole på at intuisjonen alltid tek rette val - berre dei lettaste vala. Me vel det som me har gjort før og som me veit fungerer. Skal me gå imot dette må me aktivt lære oss å handle annleis. Dette er eit kjent paradoks innan friimprovisasjon, at den tilsynelatande fridomen vert ein illusjon når handlingar og åtferd i for stor grad er automatiserte.

Vår lytteevne er vår auditive førestilling om verda. I eit fritt improvisert samspel vil vår lytteevne påverka dei musikalske vala me tek undervegs og korleis me tolkar medspelarane våre; den er både reseptiv òg skapande. Me tek imot auditive sanseinntrykk, tolkar og responderer på same tid. Det er ikkje ein kognitiv tilstand, meir ein prekognitiv flyt.

Den lyttinga eg gjer i analysearbeidet er ei reseptiv, mottakeleg lytting. Men det står klart føre meg etter dette analysearbeidet at det nære samspelet mellom desse måtane å lytte på er avgjerande for det improviserande samspelet som følgjer etter. Ein nyttar ofte omgrep som "komposisjon i sanntid» eller «notidskunst» om improvisasjon, men i dette «no» ligg det lag på lag med læring. Det er ikkje den same elva me går ut i neste gong: vår auditive merksemd er endra, og med det våre førestillingar om verda.

Den auditive sonologianalysen er eit reiskap for å bli ein betre lyttar. Metoden hjelper oss til å konkretisere kva som faktisk skjer i samspelet; kva verkemiddel og klangkarakterar ein vanlegvis brukar, kva posisjonar den enkelte spelaren tek i samspelet, og kva formdanningar og formtransformasjonar bandet utviklar saman. På denne måten er analysearbeidet frigjerande i høve til improvisasjonsarbeidet. Ein analyse kan gje idear og innspel til endra åtferd, den kan peike på manglar eller avgrensingar i klangbruk og samspelsposisjonar. Denne informasjonen kan ein ta med seg vidare i øvingsarbeidet, både på instrumentet og i samspelet - og kanskje bli ein betre utøvar.

\section{Forfattaromtale}

Njål Ølnes har bakgrunn som jazzsaksofonist og engasjert pedagog på jazzfeltet. For tida er han postdoktor ved jazzlinja på NTNU - Institutt for musikk, og forskar på samanhengen mellom improvisert samspel og det kollektive minnet. Ølnes har sidan 2006 hatt trioen BMX, med gitarist Thomas T. Dahl og trommis Øyvind Skarbø, som sitt musikalske hovudprosjekt. Frå 2008 har dei oftast spela kvartett med Per Jørgensen på vokal/ trompet, og frå 2017 finnest dei òg som sekstetten BmXL, med Eirik Hegdal og Ståle Storløkken. I 2016 tok Ølnes sin doktorgrad ved Norges musikkhøgskole, med BMX som «forskningsobjekt» og musikarane i BMX som medforskarar/forskingsdeltakarar.

\section{Referansar}

Borgdorff, H. (2011). The Production of Knowledge in Artistic Research. I M. Biggs \& H. Karlsson (red.), The Routledge Companion to Research in the Arts (s. 44-64). London: Routledge. 


\section{N. Ølnes}

Biggs, M. and Büchler, D. (2011). Communities, values, conventions and actions. I M. Biggs \& H. Karlsson (red.), The Routledge Companion to Research in the Arts (s. 82-99). London: Routledge.

Crispin, D., Coessens, K. \& Douglas, A. (2009). The Artistic Turn: a manifesto. Leuven: Leuven University Press. Crispin, D. ( 2016). Webtekst, upublisert NMH-publikasjon. Oslo: Norges Musikkhøyskole.

Frayling, C. (1993). Research in Art and Design. Royal College of Art Research Papers, 1 (1), 1993/4, 1-5.

Hannula, M., Suoranta, J. \& Vadén, T. (2014). Artistic Research Methodology. Narrative, Power and the Public. New York: Peter Lang.

Horowitz, S. (2012). The Universal Sense: How Hearing Shapes the Mind. NY: Bloomsbury.

Johannessen, K.J. (2014). Tanker om taus kunnskap. Upublisert tekst i samband med NMH-seminar.

Johannessen, K.J. (1994). Wittgensteins senfilosofi. En skisse av noen hovedtrekk. Filosofisk institutts stensilserie nr. 42. Bergen: Universitetet i Bergen.

Johannessen, K.J. (2001). Tradisjoner og skoler $i$ moderne vitenskapsfilosofi. Bergen: Fagbokforlaget.

Kahneman, D. (2011). Thinking: Fast and Slow. London: Penguin.

Kara, H. (2015). Creative Research Methods in the Social Sciences. A Practical guide. Bristol and Chicago: Policy Press.

Koffka, K. (1963/1935). Principles of Gestalt Theory. New York: Harcourt, Brace \& Co.

Lilja, E. (2015). Art, Research, Empowerment: The Artist as Researcher. Stockholm: Regeringskansliet i Sverige.

Polanyi, M. (1966). The Tacit Dimension. Chicago: The University of Chicago Press.

Schaeffer, P. (1977/1966). Traité des objets musicaux. Paris: Seuil.

Smalley, D. (1997). Spectromorphology: Explaining Sound-Shapes. Organised Sound, 2 (2), 107-126.

Snyder, B. (2000). Music and Memory: An Introduction. Cambridge, MA: The MIT Press.

Thoresen, L. (2015). Emergent Musical Forms: Aural Explorations. WO: Studies in Music of the University of Western Ontario.

Wittgenstein, L. (1977). Bemerkungen über die Farben. Omsett av Linda McAlister og Margarete Schättle. Berkeley og Los Angeles: University of California Press.

Ølnes, N. (2016). Frå små teikn til store former: Analysar av det improviserte samspelet med hjelp av auditiv sonologi. (Diss.) Oslo: NMH-publikasjoner.

\section{Digitale referanser}

Analysefilm av brot og fordeling av klangkarakterar, BMX: https://vimeo.com/222394527/4a0468be59 (tilgang 14.10.2017)

Analysefim av dynamisk form og formtransformasjonar i BMX: https://vimeo.com/222395836/b428c13f3e (tilgang 14.10.2017)

Analysefilm av sjikt i BMX: https://vimeo.com/222411668/9b38ca3d9c (tilgang 14.10.2017)

Om A/r/tography: http://artography.edcp.educ.ubc.ca/?page_id=69a (tilgang 14.01.2017)

Oversikt over typologi for klangobjekt og tidsfelt i auditiv sonologi: http://www.auralsonology.com/the-signs/ chapter-4-spectromorphology/ http://www.auralsonology.com/the-signs/chapter-6-time-fields/ (tilgang 14.10.2017)

Oversikt over typologi for for klangobjekt, norsk oversetjing: kapittel 6-8 i (Ølnes, 2016, s. 81-92, 118-125 og 140-147) https://brage.bibsys.no/xmlui/handle/11250/2381966 (tilgang 14.10.2017)

Oversikt over typologi for sjiktanalyse: http://www.auralsonology.com/the-signs/chapter-7-layers/ (tilgang 14.10.2017)

Oversikt over typologi for dynamisk formanalyse: http://www.auralsonology.com/the-signs/chapter-8-dynamicforms/ (tilgang 14.10.2017)

Oversikt over typologi for analyse av formdannande transformasjonar: http://www.auralsonology.com/the-signs/ chapter-9-form-building-transformations/ (tilgang 14.10.2017) 